Przegląd Badań Edukacyjnych Educational Studies Review

ISSN 1895-4308

nr 27 (2/2018), s. 129-148

METAANALIZY

BADAŃ

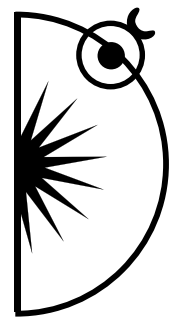

Magdalena Zadworna-Cieślak

ORCID iD: 0000-0002-0585-019X

Uniwersytet Łódzki, e-mail: magdalena.zadworna@uni.lodz.pl

Karolina Kossakowska

ORCID iD: 0000-0003-3618-1918

Uniwersytet Łódzki, e-mail: karolina.kossakowska@uni.lodz.pl

\title{
The Subjective Mental Well-Being of School-Age Children - Educational and Prophylactic Challenges
}

http://dx.doi.org/10.12775/PBE.2018.021

\begin{abstract}
The World Health Organization (WHO) regards the concept of health as individual psychosocial well-being based not only on physical, but psychological, social and environmental factors. Due to the long time spend at school, that context exerts a strong influence on the well-being of children and adolescents and plays an important role in their physical and mental health. Good mental condition in childhood and adolescence is a prerequisite for optimal development, effective learning, the formation of satisfying interpersonal relationships, and for maintaining physical and mental health in adult life. The aim of this paper is to describe the concept of socio-psychological well-being at school and major factors that influence it. Research about well-being of Polish adolescents will also be reviewed. Some preventive and educational implications will be drawn. Childhood and adolescence are crucial periods for the promotion of mental health and the prevention of mental disorders. The article is based on the assumption that the school environment is one of the key elements affecting the subjective psychological well-being of pupils. The school context is also necessary for taking appropriate preventive action and support school-age children in developing appropriate competences.
\end{abstract}

Key words: school, student, school-age children, subjective well-being, social competencies, prophylactics. 


\section{Socio-psychological well-being at school}

Ryff (1989) regards psychological well-being as positive psychological health; this state is characterised by positive evaluations of oneself and one's past life, a sense of continued growth and development as a person and the belief that one's life is purposeful and meaningful; it also demands the possession of quality relations with other people, the capacity to manage one's life and world and a sense of self-determination. A similar term is subjective well-being; this refers to a person's cognitive and affective evaluations of his or her life, including both emotional reactions and cognitive judgements of satisfaction (Diener et al., 2002, p. 63).

As health and well-being have mostly been separated from other aspects of school life, we can also discuss well-being at school. The School Well-being Model, based on Allardt's sociological theory of welfare, assesses well-being as an entity in a school setting. Well-being in this sense is connected with teaching and education, and with learning and achievements. Indicators of well-being are divided into four categories: school conditions (having), social relationships (loving), means for self-fulfilment (being) and health status (Allard, 1989; after: Konu and Rimpela, 2002). Research has shown that the school context has a major influence on the general subjective feeling of well-being reported by pupils (Konu et al., 2002).

Learning for socio-psychological well-being within school can be seen as an active, collaborative and situated process in which the relationship between individuals and their environment is constantly constructed and modified. Not only does it concern the acquisition of knowledge and skills, but it also serves as an ongoing, interactive process of sense making and development, in which motives and emotions play an important part.

\section{Well-being of Polish adolescents}

A survey of subjective well-being of children in Poland was conducted based on a representative sample of pupils aged 8,10 and 12 as a part of the International Survey of Children's Well-Being (Strózik, Strózik \& Szwarc, 2016). The degree of satisfaction with life demonstrated by children turned out to be high. The highest mean values for all scales were observed among eight-year-olds, while the worst assessment of their lives was provided by 12 -year-olds. The average level of life satisfaction was similar for both sexes. In all age categories, the most favourable scores were obtained for family life, and the worst for the school experience. 
Similar findings were obtained by the Health Behaviour in School-Aged Children (HBSC) study, a WHO collaborative cross-national study intended to provide information about the health, well-being, social environment and health behaviour of adolescents. HBSC 2014 was carried out in Poland in the school year 2013-2014; it examined a representative national sample of 4,545 students from all regions of Poland, divided into three groups with mean ages of 11.6, 13.6 and 15.6 years. Among these subjects, $33.6 \%$ of the pupils declared a very high level of well-being, $47 \%$ a medium level, and $20 \%$ a low level of wellbeing. The mean level of well-being was found to be 7.38 points $(\mathrm{SD}=2.13)$ on the 10-point Cantrill Ladder scale. In addition, the HSBC results revealed lower satisfaction with life in girls than boys, as well as in older than younger people (Mazur, 2015); the latter was previously noted in a number of national and international studies which also found life satisfaction to decrease with age in both children and adolescents (Casas, 2011; Currie et al., 2012; Goswami, 2014). Self-perception, parental relations, moods and emotions, the school environment and some socioeconomic factors are known to have a dominant influence on adolescent well-being (Mazur et al., 2016). Although the self-assessment of well-being given by Polish teenagers is quite high, the group reported many examples of high-risk behaviours and a lack of pro-health behaviours; these two ways of measuring well-being can give a fuller picture of well-being in adolescents.

Social changes in Poland during recent years have led to changes in risk behaviours of Polish teenagers, with both positive and negative changes being observed. For example, they report becoming intoxicated less frequently using alcohol but more so with marijuana. Negative changes have also been observed in the sphere of violence and injury, with more frequent injuries requiring medical assistance and an increased percentage of young people experiencing violence from their peers. Further negative changes have been seen in the perception of some aspects of school and home environments: for example, boys report worsening communication with mothers, greater school-related stress and repeated fights. Interestingly, while boys were involved in fewer fights in the period 2010-2014, the same period saw a significant increase in girls. While boys demonstrated positive changes concerning better school achievements and general life satisfaction, girls reported more frequent smoking, worse communication with fathers and intensification of repeated subjective complaints (Mazur, 2015).

Poland is ranked next to bottom among European countries with regard to the well-being of teenagers, especially 15 -year-olds (Inchley et al., 2016). 


\section{Major factors influencing school well-being}

Among the many factors influencing the mental health of children, the factors most strongly associated with school well-being appear to be family and family relationships, school performance and school environment, quality of peer relationships and personal / individual resources (see: Fig. 1).

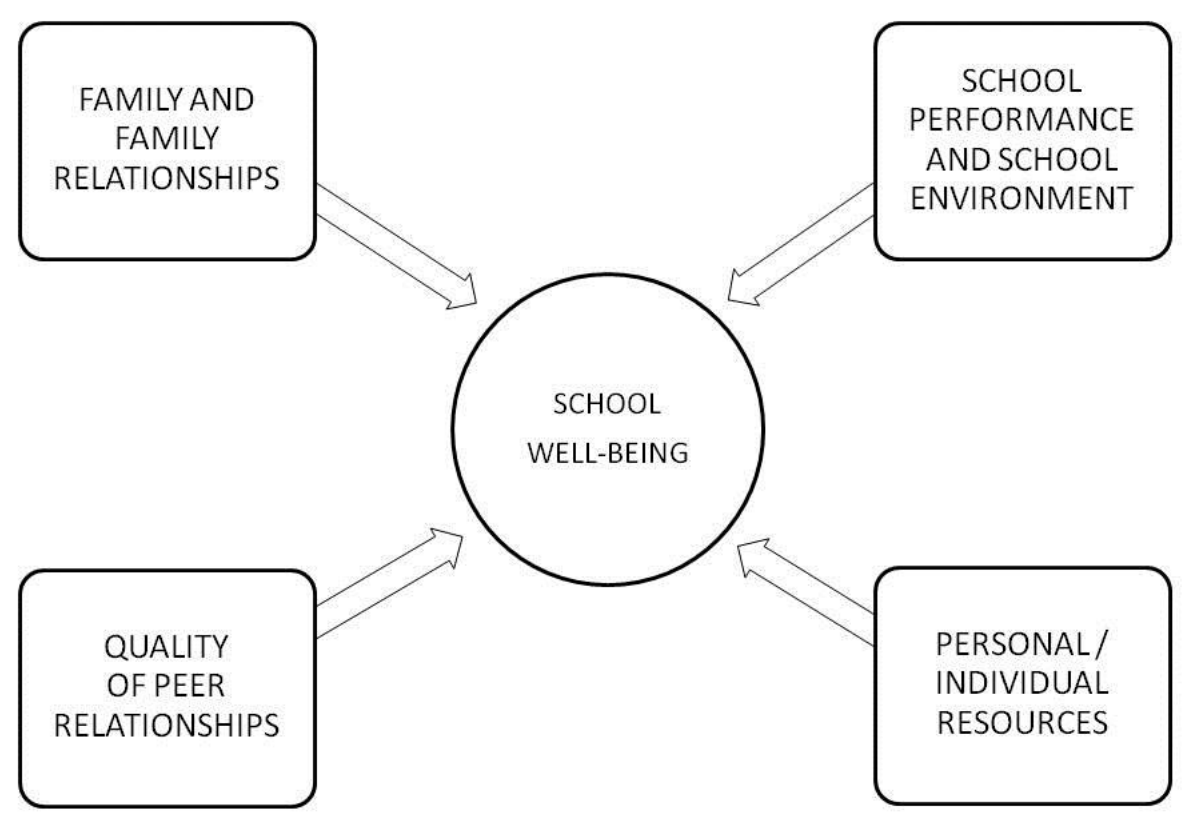

Fig. 1. Factors influencing school well-being Source: own study.

Family serves as the background to the process of socialisation, creating lifestyle patterns and building personal resources and values. Adolescence is a crucial time for building psychological well-being, and family relations play the most important role in this process. Support, adequate control, positive parental attitudes, discipline and effective communication with family members strengthen psychological development. Research has shown that family functioning is significantly related to measures of adolescent psychological wellbeing (existential well-being, life satisfaction, self-esteem, sense of mastery, general psychiatric morbidity), school adjustment (perceived academic performance, satisfaction with academic performance, and school conduct), and 
problem behaviour (delinquent and substance abuse behaviour) (Shek, 2002). Adolescents who were more satisfied with their quality of life reported fewer symptoms of depression and had families whom they perceived as being warmer and more caring (Grey et al., 1998). On the other hand, children who experience multiple transitions in the family structure may face poorer developmental outcomes than those raised in stable families (Fomby \& Cherlin, 2007). In addition, the quality of family life is closely associated with the psychological well-being of adolescents (Armsden \& Greenberg, 1987). Arguments with parents and worrying about family relationships are more likely to contribute to psychological distress in younger people than changes to the family structure (Sweeting et al., 2010).

Healthy development of the child is influenced to a great degree by his or her attachment to the parent, and disturbances in parental bonding have been associated with the development of mental disorders later in life. Subjects who reported high care and low control (optimal bonding) reported less distress, better general well-being and better social support than all other groups. These results are in line with Bowlby's theory of attachment (Bowlby, 2007). They also show that specific configurations of parental bonding are linked with distress and isolation in adolescents (Canetti et al., 1997).

There is strong evidence that programs focused on parental attitudes are effective for fostering well-being in families and children (Glăveanu, 2012). Parent training programs increase perceived parental competence and can be an important preventive strategy to enhance parental and children feelings of satisfaction (Löfgren et al., 2017).

Families live in a very busy time nowadays. Adults and children alike face numerous demands in their over-scheduled lives. Spending time together with family members is the basis for adolescent development. Each time an experience is shared, the bond between all those involved grows stronger. For parents, spending quality time with children is important to help them get to know them. Families that have quality leisure time together are more likely to be satisfied than families that do not (Hodge et al., 2015). Melton and Zabriskie (2016) suggest that the best predictor of happiness in the context of family leisure is the amount of quality family leisure time spent in familiar activities at home.

To give a fuller picture of the quality of life, traditional indicators have been complemented by Quality of Life Indicators (Eurostat, 2013). One such indicator is leisure, i.e. time spent outside productive activities, has a major impact on the sense of well-being, happiness and life satisfaction. In addition, social interactions, a related but conceptually different issue, can be considered 
as providing social capital for both individuals and society and can affect the quality of life in numerous ways. Apart from its basic function of meeting the natural human need for socialising, more frequent and more rewarding social interaction is also associated with better health, improved chances of finding a job and even living in a better neighbourhood, such as one with less crime. More specifically, having someone to rely on in case of need is particularly important; it was chosen as a headline indicator for the United Nations World Happiness report (Brajša-Žganec et al., 2011).

Another group of factors influencing well-being are school factors connected with school performance and the school environment. Studies have found school performance, school attendance, teacher interaction and school/ leisure conflict to all be dimensions of adolescent stress, and all are significantly associated with psychological distress (Sweeting et al., 2010). Furthermore, a heightened emphasis on achievement in schools may marginalise and demotivate students identified as unlikely to succeed. School disengagement has been associated with negative psychological and behavioural outcomes (Sweeting et al., 2010).

Engagement and success at school constitute an important marker of students' well-being, and improved well-being has a positive effect on academic performance (Durlak et al., 2011; Franklin et al., 2009). In fact, recent studies have made strong links between academic outcomes and the quality of relationships in schools, pro-social behaviour and resilience (Department of Education..., 2010). Research findings consistently highlight the existence of a relationship between addressing the social outcomes of children and their subsequent positive academic outcomes.

Student perceptions of interpersonal teacher behaviour have been found to predict student well-being (Van Petegem et al., 2008). The social-emotional competence displayed by the teacher is crucial for promoting a positive learning environment to students (Hen and Goroshit, 2016), and suitable training methods significantly improved the attitude of the teacher towards children, as well as the ability to listen empathically and confront appropriately (Percy, 1990).

Educational, i.e. key, learner competencies /cognitive abilities and teacher competencies should be included among the skills that affect performance at school and the school environment. These key competences include knowledge, skills and attitudes that help learners obtain personal fulfilment, find work and play a role in the society; these are thought to be important for a successful personal life and a well-functioning society (Rychen \& Salganik, 2003). These key competences include "traditional" skills such as communication in one's moth- 
er tongue, foreign languages, digital skills, literacy and basic skills in Maths and Science, together with "horizontal" skills such as learning to learn, social and civic responsibility, initiative and entrepreneurship, cultural awareness and creativity. The European Commission works with EU countries to promote the development of these skills at schools.

All skills can be strengthened by various approaches. One such approach involves the use of biofeedback, a mind-body technique in which individuals learn how to modify their physiology for the purpose of improving physical, mental, emotional and spiritual health (Frank at al., 2010).

The development of problem-solving skills correlates positively with adaptive personality variables (basic hope, optimism, self-efficacy, general self-respect, extroversion and conscientiousness), but negatively with anxiety, depression and neuroticism (Laguna et al., 2005). It has been found that addressing child antisocial behaviour with the use of a combination of problemsolving skills training (PSST) and parent management training (PMT) led to more marked changes in child and parent functioning, and resulted in a greater proportion of younger people being described within the range of nonclinical (normative) levels of functioning (Kazdi et al., 1992).

Peer relationships are the next important group of factors influencing well-being. After joining school, pupils enter a broad social environment. The opinion of the group is important for a child, as well as belonging to the group. But in adolescence, the most important developmental need is to remain within the peer group, as it meets the adolescent need for discretion, security and acceptance. One such group is formed in the classroom: a team formed of students who differ in their occupied positions and roles and have a common system of values and norms regulating their behaviour in important class issues. Hence, the term peer relationships refers to three aspects of experience with peers: the first two being peer acceptance and friendship (Gottman \& Mettetal, 1986), which some authors believe should be distinguished as both are related to wellbeing among school children (Parker and Asher, 1993), with the third being loneliness or subjective feelings about the adequacy of the peer relationship (Asher, Hymel, \& Renshaw, 1984).

Another important ability affecting peer relationships is empathy. There are many reasons why students should learn empathy, thus enhancing emotional intelligence. Empathy fosters the understanding of other people and allows appropriate assistance to be provided. In today's world, empathy may be associated with other aspects; for example, empathy skills allow us to become a more attractive conversation partner. Empathic people feel heard, understood and 
needed, which may increase the chance of creating new friendships, or starting a happy relationship; furthermore, certain professions demand an ability to empathise. Having this skill will, therefore, significantly contribute to mental well-being. On the other hand, many studies indicate a strong link between the existence of bullying, which significantly lowers psychological well-being, and low levels of empathy (i.e. Raskauskas et al., 2010; Schultze-Krumbholz \& Scheithauer, 2009). Hollingsworth et al. (2003) give the three key benefits of empathy in education as:

1. Empathy builds a positive classroom culture.

2. Empathy strengthens community.

3. Empathy prepares students to be leaders in their community.

All of these benefits will also have a positive impact on mental well-being. The importance of the cognitive aspect of empathy (perspective taking) for the improvement of psychological well-being has also been demonstrated in a very recent study by Choi et al. (2016).

Another group of abilities with great importance for peer relationships are communication skills, as these exist within the social and emotional sphere, and are needed for good mental health, well-being, learning, motivation to achieve and cooperate, and the development of values. These skills affect the ability of young people to protect themselves against various health threats, to build the skills needed for positive behaviour and to strengthen healthy relationships with other people. Empirical studies show that possessing communication and interpersonal skills correlates positively with mental well-being, general life satisfaction and the quality of interpersonal relationships, but also the use of social support and effective strategies for, among other things, coping with stress and proper social functioning. The lack of these skills was found to be associated with various types of mental disorders, somatic symptoms, a sense of loneliness, criminal behaviour and addictions (Austin, Saklofske \& Egan, 2005; Cherniss, 2002; Schutte et al., 2002).

The final, but probably the most important group of factors influencing well-being are personal resources. The term "personal resources" has no clear definition, but is usually seen in the context of coping with stress. It has been proposed that they are mediators which can act as buffers against the stress experienced while struggling with a variety of life events, thus preventing the events from being harmful or threatening. In this sense, personal resources represent the most common biological, psychological and social characteristics that have a positive effect on coping with stressors. The transactional concept of stress by Lazarus and Folkman (1984) considers all the resources employed 
to manage this process. Hobfol (2002) defines resources as the properties that are in themselves valuable, or become valuable as a means to achieve other important objectives, while Moos and Schaefer (1993) regard them as a complex system of personality and cognitive factors forming a part of the context of psychological coping. Resources can influence the intensity of experienced stress, which in turn affects psychological well-being. It is recognised that people who have a higher level of resources are probably less likely to perceive various events as stressful, they solve problems more quickly and thus have the potential to increase resources. Poprawa (1996) lists the most-frequently mentioned personal resources as social support, a sense of personal control over stressful events, self-esteem, slightly inflated self-esteem and self-acceptance, generalised self-confidence, optimism, self-efficacy and the ability to cope with difficult situations.

The group of skills associated with coping with stress are also important for well-being. Research indicates that stress at school is the greatest contributor to depression, self-harm and attempted suicide among young people. Psychological well-being can also be defined as the notion of intrapersonal well-being, and is associated with an internalised sense of self and the capacity to function in one's environment. Specific characterisations include autonomy, a sense of purpose, resilience, a sense of self, self-efficacy and optimism (Fraillon, 2004; Pollard \& Lee, 2003); all these factors are affected when an individual experiences stress. The intensity of perceived stress may be regarded as a direct factor in differentiating mental well-being. Czapiński (2011) demonstrated that strategies for coping with stress differentiate levels of psychological well-being, independently of the intensity of the stress. People using an active strategy focused on the task demonstrate better indicators of well-being than those who use passive emotional strategies.

A very important personal resource is self-esteem. Self-esteem is defined as an evaluation of our worthiness as individuals, a judgment that we are good, valuable people. James (1890) regards self-esteem as an important aspect of our mental health, which is thus connected with our well-being. A meta-analysis by Baumeister of over 15,000 journal articles of self-esteem found that the majority indicated that self-esteem is positively associated with adaptive outcomes (Baumeister, 1998; after: Neff, 2011). This also suggests that it is associated with mental well-being. 


\section{Implications for prophylactics and education}

Selected aspects of mental well-being and the factors that contribute to wellbeing are described above. For each dimension (factor), it is possible to develop skills and abilities that have a positive effect on mental well-being. Table 1 presents the proposals to support and develop these skills as an example of good practice, and their effects.

Table 1. Factors affecting school well-being, associated skills and examples of supported good practices

\begin{tabular}{|c|c|}
\hline & EXAMPLES OF GOOD PRACTICES \\
\hline \multirow{4}{*}{$\begin{array}{l}\text { FAMILY } \\
\text { FACTORS }\end{array}$} & PARENTAL ATTITUDES / COMPETENCIES \\
\hline & $\begin{array}{l}\text { Parent training program (np. Parent Effectiveness Training - P.E.T.) (Gordon, 2008; Wyatt } \\
\text { Kaminski, 2008). } \\
\text { Aims/goals: } \\
\text { developing parental competences e.g. democratic style, no use of parental power; communica- } \\
\text { tion and conflict resolution skills, acceptance of child as s/he is, authentic, congruent expression } \\
\text { of true feelings without blame, avoidance of labels and judgments, family rule-setting. } \\
\text { Procedures: } \\
\text { The parent training class usually consists of brief lectures, demonstrations, workbook exercises, } \\
\text { role-playing, a lot of coaching, some homework and small group discussion. } \\
\text { Benefits for Parents: Parent Effectiveness Training (P.E.T.) is a system of training communication } \\
\text { skills in parents. } \\
\text { Benefits for Children: The PET is claimed to improve their ability to discuss their problems and } \\
\text { concerns with parents, increase self-discipline and self-control, and foster an inner sense of } \\
\text { personal responsibility, lessen anger outbursts and encourage problem-solving. }\end{array}$ \\
\hline & FAMILY TIME MANAGEMENT \\
\hline & $\begin{array}{l}\text { Various forms of family interactional events, conducted by schools or other institutions, such } \\
\text { as psychological workshops, sports and art events, and family competitions (DeVault, 2000; } \\
\text { Harrington, 2015). } \\
\text { Aims/goals: } \\
\text { To raise awareness of the role and importance of family integration; } \\
\text { To improve the cooperation skills of all family members (parents and siblings); } \\
\text { To create new forms of family leisure; } \\
\text { To improve time management skills; } \\
\text { To develop the skills of receiving and giving feedback; } \\
\text { To strengthen family bonds. } \\
\text { Procedures: } \\
\text { A series of workshops/events during which family members develop new forms of spending } \\
\text { leisure time. The events incorporate active learning methods, sports competitions, self-support } \\
\text { groups and others. } \\
\text { Benefits: } \\
\text { Improve the ability of the family to spend leisure time to strengthen the quality of family life. }\end{array}$ \\
\hline
\end{tabular}


Table 1. cd.

\begin{tabular}{|c|c|}
\hline \multirow{4}{*}{$\begin{array}{l}\text { SCHOOL } \\
\text { PERFOR- } \\
\text { MANCE }\end{array}$} & KEY COMPETENCES - PROBLEM SOLVING \\
\hline & $\begin{array}{l}\text { Problem solving/decision making workshops (Kelman, 1996; Klein, 2010). } \\
\text { Aims/goals: } \\
\text { Using both cognitive and behavioural techniques and focusing on the child more than on the } \\
\text { parents or the family unit, problem-solving workshops help the child gain the ability to self- } \\
\text {-manage thoughts and feelings and interact appropriately with others by developing new per- } \\
\text { spectives and solutions. } \\
\text { Procedures: } \\
\text { A number of group or individual sessions are conducted, perhaps once a week, for several } \\
\text { months. The aim of these sessions is to encourage participants to adjust their faulty or narrow } \\
\text { perception of daily situations, confront irrational interpretations of other peoples' actions. They } \\
\text { also aim at challenging the unhelpful assumptions that may underlie problem behaviours and } \\
\text { generate alternative resolutions. } \\
\text { Benefits: } \\
\text { Increase the competences of problem solving and decision making. }\end{array}$ \\
\hline & TEACHERS COMPETENCIES \\
\hline & $\begin{array}{l}\text { Teacher Effectiveness Training (e.g. T.E.T.) (Gordon, Bruch, 1974; Percy, 1990) } \\
\text { Aims/goals: } \\
\text { Teacher Effectiveness Training (T.E.T.) offers teachers the essential communication and conflict } \\
\text { resolution skills needed for high quality relationships with students, thus preventing conflict } \\
\text { and allowing for more teaching-learning time. } \\
\text { Procedures: } \\
\text { T.E.T. is a 30-hour program designed to involve participants very actively in their own learning. } \\
\text { It uses the following four-step instructional process in each session: } \\
\text { 1. Structure: Instructor presentations, in-class reading, audio-visual aids. } \\
\text { 2. Involvement: Role-plays, workbook exercises, one-to-one skill practice. } \\
\text { 3. Process: Group discussions, one-to-one sharing and reflection to explore new knowledge } \\
\text { and insights. } \\
\text { 4. Application: Individual and group activities to consolidate knowledge and make specific } \\
\text { action plans. It involves workbook and text reading and out-of-class skill practice assignments. } \\
\text { Benefits for teachers: less stress, students demonstrate more respect and consideration for the } \\
\text { teacher, fewer classroom disruptions and conflicts, fewer discipline problems } \\
\text { Benefits for students: increased academic achievement, increased responsibility and self-con- } \\
\text { trol, a greater desire to cooperate and learn, increased ability to work in group situations. }\end{array}$ \\
\hline \multirow[b]{2}{*}{$\begin{array}{l}\text { PEER } \\
\text { RELATION- } \\
\text { SHIPS }\end{array}$} & EMPATHY \\
\hline & $\begin{array}{l}\text { Empathy lessons (Król-Fijewska, 1992; Rosenberg, 2013) } \\
\text { Aims/goals: } \\
\text { developing social skills needed to conduct empathic behaviours } \\
\text { Procedures: } \\
\text { Workshops/lessons during which students learn to recognise and express emotions, develop } \\
\text { sensitivity to other people and their emotions, and learn to accept others and understand their } \\
\text { differences. The workshops use active learning methods such as role play games. }\end{array}$ \\
\hline
\end{tabular}


Table 1. cd.

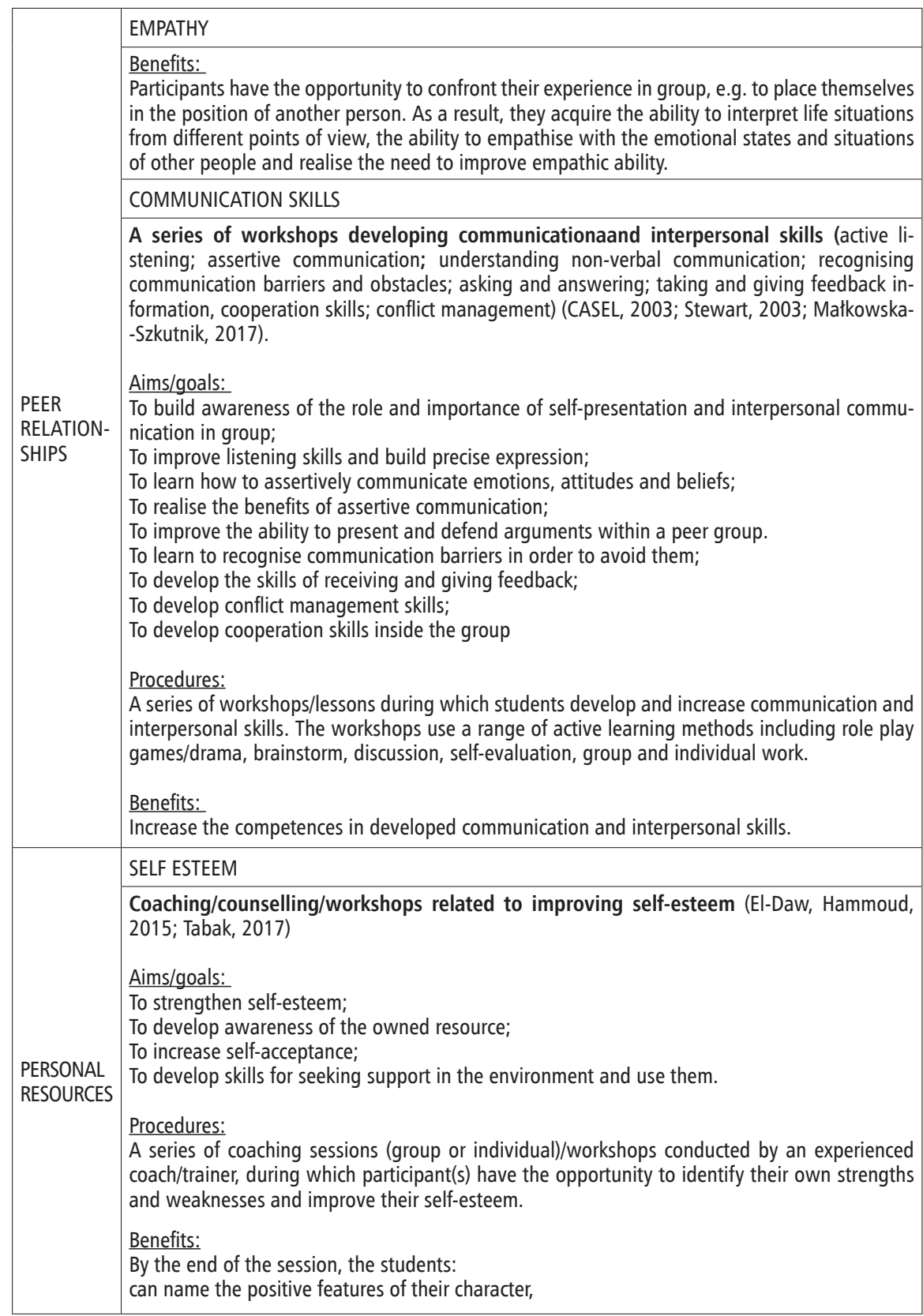


Table 1. cd.

\begin{tabular}{|l|l|}
\hline SELF ESTEEM \\
\hline $\begin{array}{l}\text { can name the qualities that distinguish them from others and contribute to their uniqueness, } \\
\text { are able to talk about their skills as a source of success, can name their own qualities that are } \\
\text { valued by others, are able to talk about themselves, and identify their positive qualities. }\end{array}$ \\
\hline $\begin{array}{l}\text { PERSONAL } \\
\text { RESOURCES }\end{array}$ & $\begin{array}{l}\text { Stress management coaching/workshops (Kraag et al., 2006; Boenish, Haney, 2007). } \\
\text { To recognise the sources of stress and/or difficult situations; }\end{array}$ \\
$\begin{array}{l}\text { To ameliorate stressful situations; } \\
\text { To adopt calming practices and seek solutions; } \\
\text { Procedures: } \\
\text { A series of coaching sessions (group or individual)/workshops conducted by an experienced } \\
\text { coach/trainer, during which participants / participant have the opportunity to identify what is } \\
\text { triggering their stress. }\end{array}$ \\
$\begin{array}{l}\text { Benefits: } \\
\text { Participants are able to use stress to train new powers to defeat it and enrich their coping } \\
\text { experience. }\end{array}$ \\
\hline
\end{tabular}

Source: own study.

Every Polish school is obligated to develop and implement promotion and prevention programs. Among other things, the quality of these programs depends on the ability of teachers and their specialist competences, as well as their adaptation of actions to the specific needs of recipients. The main domain of these programs should encompass well-being and problem behaviours of course recipients, and address protective and risk factors. Although a growing number of professionally-prepared prevention programs addressed to children and teenagers are employed in Poland (see: www.programyrekomendowane. $\mathrm{pl}$ ), there is still a need for complex well-being promotion programs dedicated to teenagers and their families. A prominent example of an initiative undertaken to support the mental well-being of school children and teenagers is the Well School Tech ${ }^{1}$ international project, which has been in operation since 2016 at

${ }^{1}$ The Well School Tech educational project (N. 2016-1-LT01-KA201-023171) is being implemented at the Faculty of Education Sciences of the University of Lodz in the framework of the Erasmus + strategic partnership since 2016. Apart from the University of Lodz, the consortium consists of partners from Lithuania (Vilniaus Kolegija - project coordinator), Italy (Promimpresa S.r.l and Instituto Superiore di Sanita), Bulgaria (European Center for Quality Ltd.) and the United Kingdom (Europa Training Ltd). As a result of the program, which promotes mental well-being and the quality of life in early adolescence, pedagogical tools will be developed to support teach- 
the University of Lodz. The aim of the project is to provide and foster the development of skills necessary to maintain mental well-being among secondary school students. The project is based on the assumption that adolescence and pre-adolescence are crucial moments for the promotion of mental health and the prevention of mental disorders. Its purpose will eventually be achieved through the development of a set pedagogical tool based on the exchange of good practices and expertise in the field of mental well-being. Partners in the project will share knowledge concerning the management of mental well-being in schools, and devise strategies intended to involve all the actors that play important roles in the mental well-being of students, i.e. teachers and family members. The main project's objectives are:

1. to exchange good practices for mental well-being management in the school context, in order to gather methodologies concerning student well-being with the direct support of the actors involved in the well-being and learning process of students: i.e. teachers and parents;

2. to provide students with tools to manage mental well-being, improve communication skills, increase self-awareness and problem solving abilities;

3. to produce high quality resources for professionals and improve their competencies to deal with diversified groups of students, making use of new technologies and learner-centred pedagogical approaches.

The subjective well-being of adolescents at school is connected with the occupational well-being of their teachers. The challenge for education is to stimulate both kinds of well-being. Managing the learning and occupational well-being of teachers is crucial in attaining educational goals, both in the classroom and at the school community level. Interaction with pupils in socially and pedagogically-challenging situations represents a core element of the pedagogical well-being of teachers. The welfare of the teacher requires success in achieving both pedagogical goals and more general social goals. This pedagogical well-being is centrally generated in the challenging social interactions of the teacher's work. Moreover, the way in which the teacher acts in a situation is believed to regulate the well-being of an experienced teacher (Soini et al., 2010).

ers and educators in coping with complex school-based problems and prophylaxis of problem behaviors by including them in the target group activities. Among the goals, there are: developing interventions to help and / or improve the ability to define personal goals, developing effective communication skills (including positive and negative emotions), and equipping students with effective strategies for addressing school and personal problems, including anger management, emotional control and response. 


\section{References}

Armsden, G. C., \& Greenberg, M. T. (1987). The inventory of parent and peer attachment: Individual differences and their relationship to psychological well-being in adolescence. Journal of Youth and Adolescence, 16(5), pp. 427-454, DOI: https://doi.org/10.1007/ BF02202939.

Asher, S. R., Hymel, S., \& Henshaw, P. D. (1984). Loneliness in children. Child Development, 55, pp. 1456-1464, DOI: https://doi.org/10.1111/bjdp.12020.

Austin, E. J., Saklofske, D. H., \& Egan, V. (2005). Personality, well-being and health correlates of trait emotional intelligence. Personality and Individual Differences, 38, pp. 547-558, DOI: http://dx.doi.org/10.1016/j.paid.2004.05.009.

Baumeister, R. F., Campbell, J. D., Krueger, J. I., \& Vohs K. D. (2003). Does high selfesteem cause better performance, interpersonal success, happiness, or healthier lifestyles? Psychological Science in the Public Interest, 4, pp. 1-44, DOI: https://doi. org/10.1111/1529-1006.01431.

Boenisch, C., Haney, C. (2007). Twój stres. Sens życia, równowaga i zdrowie. Gdańsk: Gdańskie Wydawnictwo Psychologiczne.

Bowlby, J. (2007). , Attachment”[Przywiązanie]. Warszawa: Wydawnictwo Naukowe PWN.

Brajša-Žganec, A., Merkaš, M., \& Šverko, I. (2011). Quality of life and leisure activities: How do leisure activities contribute to subjective well-being? Social Indicators Research, 102(1), pp. 81-91, DOI: http://dx.doi.org/10.1007/s11205-010-9724-2.

Canetti, L., Bachar, E., Galili-Weisstub, E., De-Nour, A. K., \& Shalev, A. Y. (1997). Parental bonding and mental health in adolescence. Adolescence, 32(126), pp. 381-394.

Casas, F. (2011). Subjective social indicators and child and adolescent well-being. Child Indicators Research, 4(4), pp. 555-575, DOI: https://doi.org/10.1007/s12187-010-9093-z.

Collaborative for Academic, Social, and Emotional Learning (CASEL). (2003). Safe and sound: An educational leader's guide to evidence-based social and emotional learning programs. Chicago, IL. http://www.casel.org/library/safe-and-sound-an-educationalleaders-guide-to-evidence-based-social-and-emotional-learning-sel-programs-2005 [access: 2018-01-19]

Currie, C., Zanotti, C., Morgan, A., et al. (2012), Social determinants of health and wellbeing among young people. Health Behaviour in School-Aged Children (HBSC) study: international report from the 2009/ 2010 survey. Copenhagen: World Health Organisation. http://www.euro.who.int/_data/assets/pdf_file/0003/163857/Social-determinants-of-health-and-well-being-among-young-people.pdf [access: 2018-08-21].

Cherniss, C. (2002). Emotional intelligence and the good community. American Journal of Community Psychology, 30, pp. 1-11, DOI: https://doi.org/10.1023/A:1014367914754. 
Choi, D., Minote, N., Sekiya, T., \& Watanuki S. (2016). Relationships between Trait Empathy and Psychological Well-Being in Japanese University Students. Psychology, 7, pp. 1240-1247, DOI: https://doi.org/10.4236/psych.2016.79126.

Czapiński, J, \& Panek, T. (2011). Diagnoza Społeczna 2011. Warunki i Jakość Życia Polaków. Contemporary Economics, Warszawa: Rada Monitoringu Społecznego.

Department of Education and Children's Services. Annual Report, 2010. https://www.decd. sa.gov.au/sites/g/files/net691/f/decsannualreport2010.pdf [access: 2018-06-05].

DeVault, M. L. (2000). Producing family time: Practices of leisure activity beyond the home. Qualitative Sociology, 23(4), pp. 485-503, DOI: https://doi.org/10.1023/A: 1005582926577.

Diener, E., Lucas, R. E., Oishi, S. (2002). Subjective well-being: The science of happiness and life satisfaction (pp. 63-73). In: C. R. Snyder \& S. J. Lopez (ed.), Handbook of positive psychology. Oxford: Oxford University Press.

Durlak, J. A., Weissberg, R. P., Dymnicki, A. B., Taylor, R. D., \& Schellinger, K. B (2011). The impact of enhancing students social and emotional learning: A meta-analysis of school-based universal interventions. Child Development, 82(1), pp. 405-432, DOI: https://doi.org/10.1111/j.1467-8624.2010.01564.x.

El-Daw, B., \& Hammoud, H. (2015). The Effect of Building Up Self-esteem Training on Students' Social and Academic Skills 2014. Procedia-Social and Behavioral Sciences, 190, pp. 146-155, DOI: https://doi.org/10.1016/j.sbspro.2015.04.929.

Fomby, P., \& Cherlin, A. J. (2007). Family instability and child well-being. American Sociological Review, 72(2), pp. 181-204, DOI: https://doi.org/10.1177/000312240707200203.

Fraillon, J. (2004), Measuring Student Wellbeing in the Context of Australian Schooling: Discussion Paper Commissioned by the South Australian department of Education and Children's services as an agent of the Ministerial Council on Education, Employment, Training and Youth Affairs. http://www.curriculum.edu.au/verve/_resources/Measuring_Student_Well-Being_in_the_Context_of_Australian_Schooling.pdf [access: 201706-19].

Franklin, C., Kim, J. S., \& Tripodi, S. J. (2009). A meta-analysis of published school social work practice studies: 1908-2007. Research on Social Work Practice, 19(6), pp. 667-677, DOI: https://doi.org/10.1177/1049731508330224.

Glăveanu, S. M. (2012), Validating a Training Program for Parental Competence, Problems of Psychology in the 21 st Century, 2. http://www.scientiasocialis.lt/ppc/files/pdf/ Glaveanu_Vol.2.pdf [access: 2017-07-05].

Goswami, H. (2014). Children's subjective well-being: socio-demographic characteris- 
tics and personality. Child Indicators Research, 7, pp. 119-140, DOI: https://doi. org/10.1007/s12187-013-9205-7.

Gottman, J. M., Metettal, G. (1986). Speculations about social and affective development: Friendship and acquaintanceship through adolescence (pp. 192-237). In: J. M. Gottman \& J. G. Parker (eds.), Conversation of friends: Speculations on affective development. Cambridge, England: Cambridge University Press.

Grey, M., Boland, E. A., Yu, C., Sullivan-Bolyai, S., \& Tamborlane, W. V. (1998). Personal and family factors associated with quality of life in adolescents with diabetes. Diabetes Care, 21(6), pp. 909-914, DOI: https://doi.org/10.2337/diacare.21.6.909.

Harrington, M. (2015). Practices and meaning of purposive family leisure among working and middle-class families. Leisure Studies, 34(4), 471-486, DOI: https://doi.org/10.10 80/02614367.2014.938767.

Hen, M., \& Goroshit, M. (2016). Social-emotional competencies among teachers: An examination of interrelationships. Cogent Education, 3(1), DOI: https://doi.org/10.1080/233 1186X.2016.1151996.

Hobfoll, S. E. (2002). Social and psychological resources and adaptation. Review of General Psychology, 6(4), pp. 307-324, DOI: http://dx.doi.org/10.1037/1089-2680.6.4.307.

Hodge, C., Bocarro, J. N., Henderson, K. A., Zabriskie, R., Parcel, T. L., \& Kanters, M. A. (2015). Family leisure: an integrative review of research from select journals. Journal of Leisure Research, 47(5), pp. 577-600, DOI: https://doi.org/10.18666/jlr-2015-v47i5-5705.

Hollingsworth, L. A., Didelot, M. J., \& Smith J. O. (2003). REACH Beyond Tolerance: A Framework for Teaching Children Empathy and Responsibility. Journal of Humanistic Counseling, Education \& Development, 42(2), pp. 139-151. DOI: https://doi. org/10.1002/j.2164-490X.2003.tb00002.x.

James, W. (1890). Principles of Psychology. Chicago: Encyclopedia Britannica.

Inchley, J., Currie, D., Young, T., Samdal, O., Torsheim, T., et al. (2016), Growing up unequal: gender and socioeconomic differences in young people's health and well-being. Health Behaviour in School-aged Children (HBSC) study: international report from the 2013/2014 SURVEY. http://www.euro.who.int/_data/assets/pdf_file/0003/303438/ HSBC-No.7-Growing-up-unequal-Full-Report.pdf?ua=1 [access: 2017-06-17]

Kazdin, A. E., Siegel, T. C., \& Bass, D. (1992). Cognitive problem-solving skills training and parent management training in the treatment of antisocial behavior in children. Journal of Consulting and Clinical Psychology, 60(5), DOI: http://dx.doi.org/10.1037/0022006X.60.5.733. 
Kelman, H. C. (1996). Negotiation as interactive problem solving. International Negotiation, 1(1), pp. 99-123, DOI: 10.1207/s15327949pac0503_2.

Klein, G. (2010). Sztuka podejmowania decyzji. Gliwice: Helion.

Konu, A. I., Lintonen, T. P., \& Rimpelä, M. K. (2002). Factors associated with schoolchildren's general subjective well-being. Health Education Research, 17(2), pp. 155-165, DOI: $10.1093 /$ her/17.2.155.

Konu, A. I., \& Rimpela, M. K. (2002). Well-being in Schools: a conceptual model. Health Promotion International, 17, pp. 79-87, DOI: https://doi.org/10.1080/02673843.2012 .754362 .

Kraag, G., Zeegers, M. P., Kok, G., Hosman, C., \& Abu-Saad, H. H. (2006). School programs targeting stress management in children and adolescents: A meta-analysis. Journal of School Psychology, 44(6), pp. 449-472, DOI: https://doi.org/10.1093/heapro/17.1.79.

Król-Fijewska, M. (1992). Trening asertywności.Warszawa: INTRA.

Lazarus, R. S., Folkman, S. (1984). Stress Appraisal and Coping. New York: Springer Verlag.

Löfgren, H. O., Petersen, S., Nilsson, K., Ghazinour, M., \& Hägglöf, B. (2017). Effects of Parent Training Programmes on Parents' Sense of Competence in a General Population Sample. Global Journal of Health Science, 9(7), 24, DOI: 10.5539/gjhs.v9n7p24.

Łaguna, M., Trzebiński, J., Zięba, M. (2005). KNS - Kwestionariusz Nadziei na Sukces, Podręcznik. Warszawa: Pracownia Testów Psychologicznych PTP.

Małkowska-Szkutnik, A. (2017). Poszukiwanie, przyjmowanie i dawanie wsparcia (pp. 346358). In: B. Woynarowska (ed.), Edukacja zdrowotna. Warszawa: PWN.

Mazur, J. (2015), Zdrowie i zachowania zdrowotne młodzieży szkolnej w Polsce na tle wybranych uwarunkowań socjodemograficznych, Wyniki badań HBSC 2014. Instytut Matki i Dziecka, Warszawa. http://www.imid.med.pl/images/do-pobrania/Zdrowie_i_ zachowania_zdrowotne_www.pdf [access: 2018-08-21]

Mazur, J., Szkultecka-Dębek, M., Dzielska, A., Drozd, M., \& Małkowska-Szkutnik, A. (2016). What does the Cantril Ladder measure in adolescence? Archives of Medical Science, 1-8, DOI: https://doi.org/10.5114/aoms.2016.60718.

Melton, K. K., \& Zabriskie, R. B. (2016). In the pursuit of happiness all family leisure is not equal. World Leisure Journal, 58(4), pp. 311-326, DOI: https://doi.org/10.1080/16078 055.2016 .1228154 .

Moos, R. H., Schaefer, J. A. (1993). Coping Resources and Process: Current Concepts and Measures (pp. 234-257). In: L. Goldberger \& S. Breznits (eds.), Handbook of Stress. Theoretical and Clinical Aspects. New York: The Free Press.

Neff, K. D. (2011). Self-Compassion, Self-Esteem, and Well-Being. Social and Per- 
sonality Psychology Compass, 5(1), 1-12, DOI: https://doi.org/10.1111/j.17519004.2010.00330.x.

Parker, J. G., \& Asher, S. R. (1993). Friendship and friendship quality in middle childhood: Links with peer group acceptance and feelings of loneliness and social dissatisfaction. Developmental Psychology, 29, pp. 611-621, DOI: http://dx.doi.org/10.1037/00121649.29.4.611.

Percy, R. L. (1990). The effects of teacher effectiveness training on the attitudes and behaviors of classroom teachers. Educational Research Quarterly, 14(1), pp. 15-20.

Pollard, E. L., \& Lee, P. D. (2003). Child Well-being: A Systematic Review of the Literature. Social Indicators Research, 61(1), pp. 59-78, DOI: https://doi. org/10.1023/A:1021284215801.

Poprawa, R. (1996). Zasoby osobiste w radzeniu sobie ze stresem (pp. 101-136). In: G. Dolińska-Zygmunt (ed.). Elementy psychologii zdrowia Wrocław: Wydawnictwo Uniwersytetu Wrocławskiego.

Quality of life indicators, http://ec.europa.eu/eurostat/statistics-explained/index.php/Quality_of_life_indicators [access: 2017-07-05].

Raskauskas, J., Gregory, J., Harvey, S., Rifshana F., \& Evans, I. (2010). Bullying among primary school children in New Zealand: Relationships with prosocial behaviour and classroom climate. Educational Research, 52(1), pp. 1-13, DOI: https://doi. org/10.1080/00131881003588097.

Rosenberg, M. B. (2013). Wychowanie w duchu empatii. Podkowa Leśna: Wydawnictwo MiND.

Ryff, C. D. (1989). Happiness is everything, or is it? Explorations on the meaning of psychological well-being. Journal of Personality and Social Psychology, 57, pp. 1069-1081, DOI: https://doi.org/10.1037/0022-3514.57.6.1069.

Schutte, N. S., Malouff, J. M., Simunek, M., McKenley, J., \& Hollander, S. (2002). Characteristic emotional intelligence and emotional well-being. Cognition and Emotion, 16, pp. 769-785, DOI: https://doi.org/10.1080/02699930143000482.

Schultze-Krumbholz, A., \& Scheithauer, H. (2009). Social-behavioural correlates of cyberbullying in a German student sample. Journal of Psychology, 217, pp. 224-226, DOI: https://doi.org/10.1027/0044-3409.217.4.224.

Shek, D. T. (2002). Family functioning and psychological well-being, school adjustment, and problem behavior in Chinese adolescents with and without economic disadvantage. The Journal of Genetic Psychology, 163(4), pp. 497-502. DOI: https://doi. org/10.1080/00221320209598698. 
Stewart J. (ed.), (2003). Mosty zamiast murów. Podręcznik komunikacji interpersonalnej. Warszawa: PWN.

Soini, T., Pyhältö, K., \& Pietarinen, J. (2010). Pedagogical well-being: reflecting learning and well-being in teachers' work. Teachers and Teaching: theory and practice, 16(6), pp. 735-751, DOI: https://doi.org/10.1080/13540602.2010.517690.

Strózik, D., Strózik, T., \& Szwarc, K. (2016). The subjective well-being of school children. The first findings from the children's worlds study in Poland. Child Indicators Research, 9(1), pp. 39-50, DOI: https://doi.org/10.1007/s12187-015-9312-8.

Sweeting, H., West, P., Young, R., \& Der, G. (2010). Can we explain increases in young people's psychological distress over time? Social Science and Medicine, 71, pp. 18191830, DOI: 10.1016/j.socscimed.2010.08.012.

Tabak, I. (2017). Rozwijanie wybranych psychologicznych zasobów dla zdrowia (s. 311-327). In: B. Woynarowska (ed.), Edukacja zdrowotna. Warszawa: PWN.

Van Petegem, K., Aelterman, A., Van Keer, H., \& Rosseel, Y. (2008). The influence of student characteristics and interpersonal teacher behaviour in the classroom on student's wellbeing. Social Indicators Research, 85(2), pp. 279-291, DOI: https://doi.org/10.1007/ s11205-007-9093-7.

World Happiness Report 2013, Helliwell, J., Layard, R., and Sachs, J. (eds.), Eurofound, Subjective well-being in Europe, 2010. http://unsdsn.org/wp-content/uploads/2014/02/ WorldHappinessReport2013_online.pdf [access:2017-07-05].

Wyatt Kaminski, J., Valle, L. A., Filene, J. H., \& Boyle, C. L. (2008). A meta-analytic review of components associated with parent training program effectiveness. Journal of Abnormal Child Psychology, 36(4), pp. 567-589, DOI: https://doi.org/10.1007/s10802007-9201-9. 